\title{
Treatment of tibial fractures in seven cats using circular external skeletal fixation
}

\author{
İrem Gül SANCAK ${ }^{1}$, Özge ÖZDEMIR ${ }^{2}$, Sinan ULUSAN ${ }^{1}$, Hasan BILGILI ${ }^{1}$ \\ ${ }^{1}$ Department of Surgery, Faculty of Veterinary Medicine, Ankara University, Ankara; ${ }^{2}$ Department of Surgery, Faculty of Veterinary \\ Medicine, Cumhuriyet University, Sivas, Turkey.
}

\begin{abstract}
Summary: This study covers the technique of a custom designed circular external fixator (CEF) in tibial fractures in 7 cats. All tibial fractures were surgically treated. The cases were followed-up using radiographs obtained on 25 and 48 days after surgery. Signalment, fracture localization, complications and implant diameter for each cat were noted. Ring diameters were as follows: in 4 tibial fracture cases $45 \mathrm{~mm}$ and in 3 tibial fracture cases $55 \mathrm{~mm}$. Complications were observed in 2 cats, both of which had pin tract infection. Fracture cases were evaluated as follows: 5 of the tibial fractures had excellent results and 2 cases had good results. The CEF system was well tolerated by all the cats during the postoperative follow-up period. First use of the treated limb occurred on postoperative 1-3 day in all cases. Pin deformation or CEF breakage and distortion were not observed in any of the cases. The CEF system designed by the authors was suitable for fixation of tibial fractures in cats. Clinical use of CEF system in tibial fractures of cats is found to be useful and its use is highly recommended to our colleagues.

Keywords: Cat, circular external skeletal fixator, fracture, tibial fracture, tibia.
\end{abstract}

\section{Yedi kedide tibia kırıklarının sirküler eksternal fiksasyon kullanılarak sağaltımı}

Özet: Bu çalışma kedilerde Sirküler Eksternal Fiksatör tekniğinin kullanımını değerlendirmektedir. Çalışmanın konusunu özel olarak dizayn edilmiş Sirküler Eksternal Fiksatör kullanarak tibia kırıkları sağaltılan 7 kedi oluşturmuştur. Bütün tibia kırıkları cerrahi olarak sağaltılmıştır. Olguların kontrolleri; post operatif 25. ve 48. günlerde radyografik olarak yapılmıştır. Hastanın eşgali, kırığın lokalizasyonu, komplikasyonlar ve implant çapları not edilmiştir. Halka çapları 5 olguda $45 \mathrm{~mm}$ ve 2 olguda $55 \mathrm{~mm}$ olarak tercih edilmiştir. CEF sistemi postoperatif takip döneminde bütün kediler tarafindan iyi tolere edilmiştir. Tedavi edilen ekstremitenin ilk kullanımı tüm olgularda ameliyat sonrası 1-3 günde gerçekleşmiştir. Pin deformasyon veya CEF'te kırılma ve bozulma olguların hiçbirinde gözlenmemiştir. 2 kedide pin dibi enfeksiyonu komplikasyonu ile karşılaşılmıştır. 5 olguda sonuçlar mükemmel 2 olguda ise iyi olarak değerlendirilmiştir. Sirküler Eksternal Fiksatör sistemi kedi ekstremite kırıklarında kullanışlı bulunmuş ve meslektaşlarımıza tavsiye edilmektedir.

Anahtar sözcükler: Kedi, kırık, sirküler eksternal fiksatör, tibia.

\section{Introduction}

A circular external fixator $(\mathrm{CEF})^{\mathrm{a}}$ is a device that was first used primarily in humans for the fixation of bone fractures and in distraction osteogenesis (6) using pins, bars and clamps which was subsequently adapted for use in veterinary medicine $(11,16,20)$. It causes minimal damage to soft tissue, vascular supplies, and nerves and provides stable fixation of bones and joints. It is particularly useful in open and comminuted fractures with poor circulation that require prolonged fixation.

Fractures of the radius/ulna represents the $8.5 \%$ to $17.3 \%$ of all fractures in cats and dogs $(15,19)$, and fractures of the tibia account for $20 \%$ of fractures (7). Treatment options for fractures in cats include internal fracture fixation (plate rod construct, internal fixation alone and internal fixation with secondary external support) (3), cerclage wiring (full and hemicerclage wiring) (14), external skeletal fixation (9), external coaptation (5), interlocking nailing systems (9) and bone plates with screws (17). The external skeletal fixators that are used in extremity fractures of cats are mainly linear external skeletal fixators (9), use of circular external skeletal fixators in extremity fractures are limited $(4,8)$. Circular external fixators $(10)$ have high biomechanical strenght compared to linear external skeletal fixators (6).

The aim of the present study was to report the results obtained using a custom-designed (This system has different diameters, thickness and and hole numbers from the other CEF fixators) CEF system designed by the authors in cats with tibial fractures.

${ }^{a}$ Circular external fixator (CEF): Imex, Longview, Texas, USA 


\section{Materials and Methods}

This study included 7 cats with tibial fractures that were treated at our small animal clinics.

Design and construction of the CEF: The CEF system was constructed using ETAL-74 (94 \% aluminum, $1.5 \%$ magnesium, and $4.5 \%$ copper). The system employs 2 types of rings (full rings and $5 / 8$ rings), 3 ring diameters $(35,45$, and $55 \mathrm{~mm})$, connection rods ( $4 \mathrm{~mm}$ in diameter) (Figures 1a and 1b), Kirschner wires $(1.2 \mathrm{~mm})$, no. 7 nut-keys for wire fixation, and nuts and bolts. One 5/8 ring on the top and 2 full rings at the bottom are connected by rods. The $35-\mathrm{mm}$ ring has 14 holes, the $45-\mathrm{mm}$ ring has 18 holes, and the $55-\mathrm{mm}$ ring has 20 holes. Ring outer diameter, inner diameter, hole spacing, and thickness are shown in Table 1.

Preoperative planning: Craniocaudal and mediolateral radiographs were obtained in all cases (Figures 2 and 3). The following data were collected for each case: signalment and medical history, type of fracture, and CEF configuration (due to extremity thickness ring diameter, number of rings, ring type, rod length, and rod penetration depths were adjusted) (Table1).
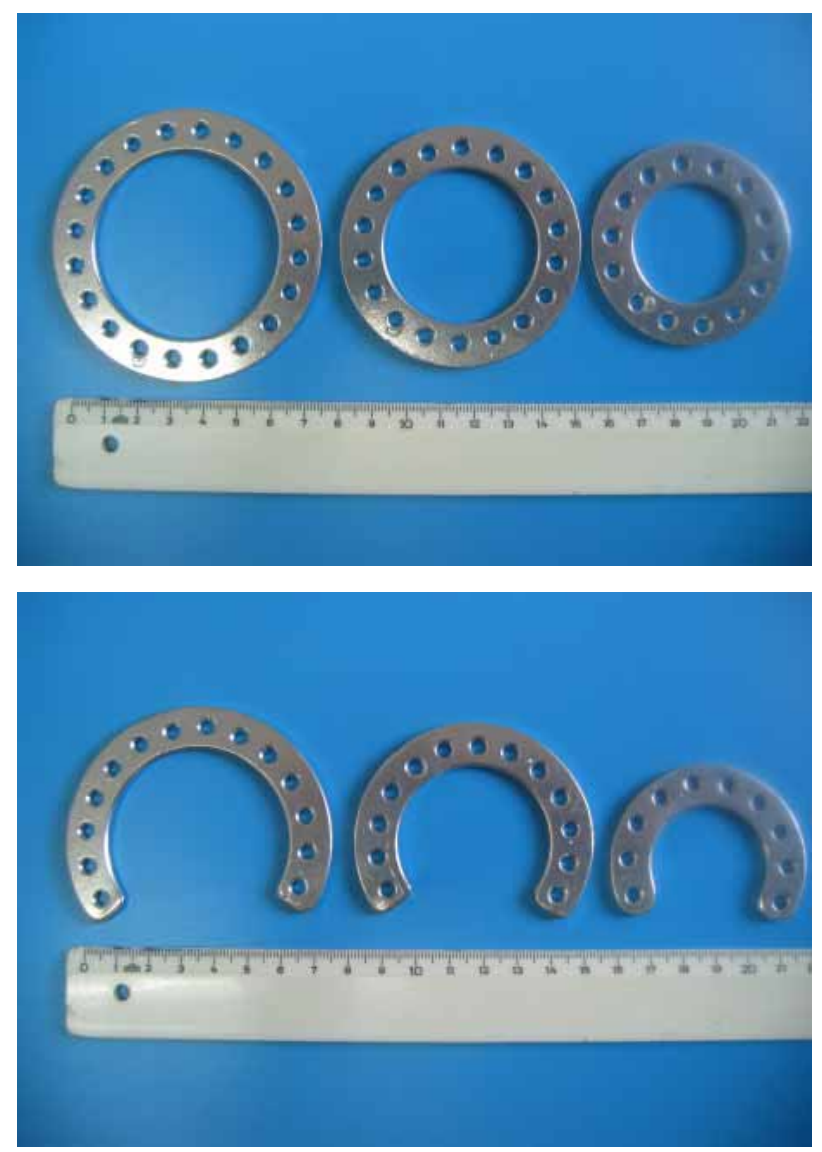

Figure 1 . The CEF system. Full rings (a) and $5 \backslash 8$ rings (b) made with ETAL-74 (94.\% aluminum, 1.5\% magnesium, and 4.5\% copper).

Şekil 1. SEF sistemi. ETAL 74 'ten (\%94 alüminyum, \% 1.5 magnezyum ve $\% 4.5$ bakır) yapılmış tam halka (a) ve $5 \backslash 8$ halka.
Anesthesia: Anesthesia was induced with xylazine hydrochloride $\left(1.1 \mathrm{mg} \mathrm{kg}^{-1}\right)$ and ketamine hydrochloride (15 $\left.\mathrm{mg} \mathrm{kg}^{-1}\right)$, and maintained with inhalation of isoflurane and oxygen.
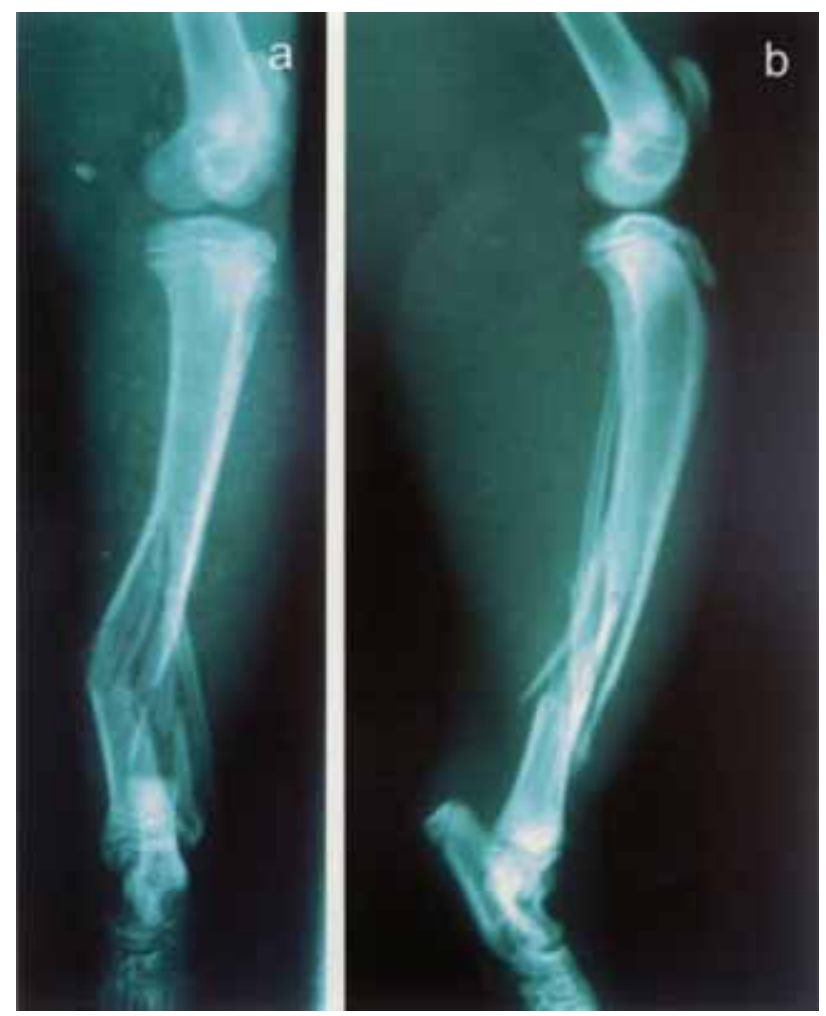

Figure 2. Preoperative craniocaudal (a) and mediolateral (b) radiographs of the right crural fracture in case 6 show a distal diaphyseal (1\3) comminuted segmental fracture.

Şekil 2. Parçalı segmental kırık ve distal diyafizer kırık gözlenen olgu 6 'da sağ krural kırığın preoperative kraniokaudal (a) ve mediolateral (b) radyografileri.
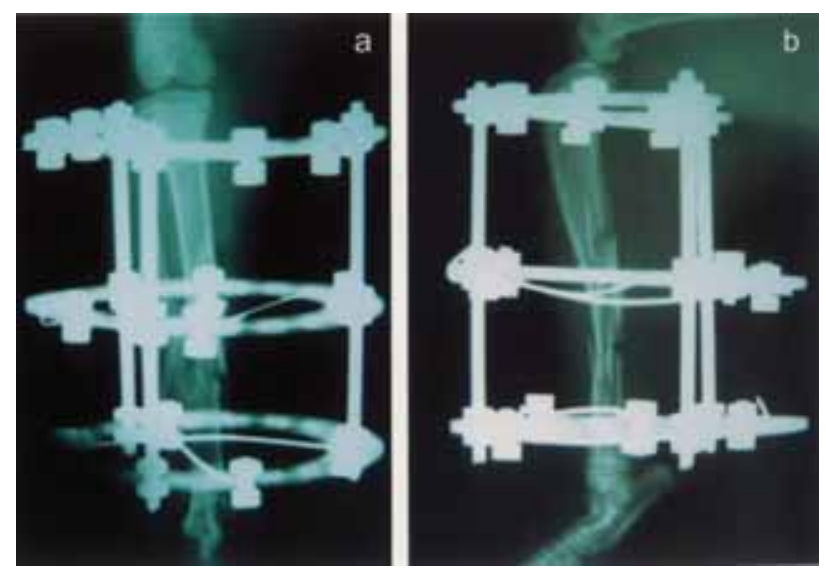

Figure 3. Postoperative kraniokaudal (a) and mediolateral (b) radiographs in case 6 show the positioning of the 3-ring CEF system. One $5 \backslash 8$ ring was used at the top and 2 full rings at the bottom.

Şekil 3. 6 no'lu olguda postoperatif kraniokaudal (a) ve mediolateral (b) grafilerde 3-halkal CEF sisteminin konumlandırılması gösterilmektedir. Bir $5 \backslash 8$ halka üstte 2 tam halka ise altta kullanılmıştır. 
Surgical Procedure: The cats were placed in lateral recumbence. The surgical site was prepared and draped for aseptic surgery. Antibiotic cefazolin $\left(22 \mathrm{mg} \mathrm{kg}^{-1}\right)$ was given intravenously to all animals before surgery. The affected limb was prepared and the custom-designed CEF system was used in all cases. Kirschner wire diameter varied by case, but was consistent in each ring; 2 Kirschner wires were used with full rings, versus 1 Kirschner wire with $5 / 8$ rings. Kirschner pins (1.2 mm in diameter) were used and were drilled into the bone with a 150-rpm pneumatic drill. The bones were positioned perpendicular to the CEF rings and were centered in the device (Figures 3 and 4). Ring diameters were as follows: in 4 tibia fracture cases: $45 \mathrm{~mm}$ and in 3 tibia fracture cases: $55 \mathrm{~mm}$. In one case $3 \mathrm{~cm}$ block resection was performed and the necrotic tissue is removed. After two days latency period $0.5 \mathrm{~mm}$ distraction rate and for two times distraction rhythm was performed daily. Distraction time was 30 days.

Postoperative follow-up: Postoperative radiographs were obtained immediately after surgery to evaluate positioning of the $\mathrm{CEF}$ and bone reduction. Cefazolin $\mathrm{Na}$

Table 1. Signalment, classification, management, fixator removal time, apparatus configuration, and outcome (clinical and cosmetic) in 7 cats with tibial fractures.

Tablo 1. Tibial kırığı bulunan 7 kedide signalment, sınıflandırma, tedavi, fiksatör çıkarma zamanı, system konfigürasyonu ve sonuçlar (klinik ve kozmetik).

\begin{tabular}{|c|c|c|c|c|c|c|}
\hline Case & Signalment & $\begin{array}{l}\text { Classification of } \\
\text { fracture and other } \\
\text { injuries }\end{array}$ & Treatment & $\begin{array}{l}\text { Fixator } \\
\text { removal } \\
\text { time }\end{array}$ & Configuration and diameter of rings & $\begin{array}{l}\text { Outcome } \\
\text { (clinical and } \\
\text { cosmetic } \\
\text { results) }\end{array}$ \\
\hline 1 & $\begin{array}{l}\text { 1y, F, Mix } \\
\text { Breed, 5kg }\end{array}$ & $\begin{array}{l}\text { Upper diaphyseal } \\
\text { region }(1 / 3) \\
\text { comminuted, } \\
\text { L tibia }\end{array}$ & $\begin{array}{l}\text { Limited } \\
\text { open } \\
\text { approach }\end{array}$ & 45 days & $\begin{array}{l}1 \text { half ring on the proximal fragment }(5 \backslash 8) \\
2 \text { full rings on the distal fragment (internal } \\
\text { diameter } 55 \mathrm{~mm}) \\
2 \mathrm{~K} \text { wires }(1.2 \mathrm{~mm}) \text { on each fragment }\end{array}$ & Excellent \\
\hline 2 & $\begin{array}{l}1.5 \mathrm{y}, \mathrm{M}, \mathrm{Mix} \\
\text { Breed, } 5 \mathrm{~kg}\end{array}$ & $\begin{array}{l}\text { Upper } \\
\text { diaphyseal (1\3), } \\
\text { comminuted, } \\
\text { L tibia }\end{array}$ & $\begin{array}{l}\text { Open } \\
\text { approach }\end{array}$ & 42 days & $\begin{array}{l}1 \text { half ring on the proximal fragment }(5 \backslash 8) \\
2 \text { full rings on the distal fragment (internal } \\
\text { diameter } 55 \mathrm{~mm}) \\
2 \mathrm{~K} \text { wires }(1.2 \mathrm{~mm}) \text { on each fragment }\end{array}$ & Good \\
\hline 3 & $\begin{array}{l}2 \mathrm{y}, \mathrm{F}, \mathrm{Mix} \\
\text { Breed, } 4 \mathrm{~kg}\end{array}$ & $\begin{array}{l}\text { Proximal }(1 \backslash 3) \text { of } \\
\text { diphysis, } \\
\text { comminuted, } \\
\text { R tibia }\end{array}$ & $\begin{array}{l}\text { Limited } \\
\text { open } \\
\text { approach }\end{array}$ & 45 days & $\begin{array}{l}1 \text { half ring on the proximal fragment }(5 \backslash 8) \\
2 \text { full rings on the distal fragment (internal } \\
\text { diameter } 45 \mathrm{~mm}) \\
2 \mathrm{~K} \text { wires }(1.2 \mathrm{~mm}) \text { on each fragment }\end{array}$ & Excellent \\
\hline 4 & $\begin{array}{l}\text { 3y, F, Mix } \\
\text { Breed, } 3.5 \mathrm{~kg}\end{array}$ & $\begin{array}{l}\text { Upper } \\
\text { diaphyseal (1\3), } \\
\text { comminuted, } \\
\text { L tibia }\end{array}$ & $\begin{array}{l}\text { Open } \\
\text { approach }\end{array}$ & 39 days & $\begin{array}{l}1 \text { half ring on the proximal fragment }(5 \backslash 8) \\
1 \text { full ring on the proximal fragment } \\
1 \text { full ring on the distal fragment (internal } \\
\text { diameter } 45 \mathrm{~mm}) \\
2 \mathrm{~K} \text { wires }(1.2 \mathrm{~mm}) \text { on each fragment }\end{array}$ & Excellent \\
\hline 5 & $\begin{array}{l}7 \mathrm{~m}, \mathrm{~F}, \mathrm{Mix} \\
\text { Breed, } 3.5 \mathrm{~kg}\end{array}$ & $\begin{array}{l}\text { Distal } \\
\text { diaphyseal (1\3), } \\
\text { comminuted, } \\
\text { segmental, } \\
\text { R tibia }\end{array}$ & $\begin{array}{l}\text { Open } \\
\text { approach }\end{array}$ & 40 days & $\begin{array}{l}1 \text { half ring on the proximal fragment }(5 \backslash 8) \\
1 \text { full ring on the upper diaphyseal region }(1 \backslash 3) \\
1 \text { full ring on the distal fragment (internal } \\
\text { diameter } 45 \mathrm{~mm}) \\
2 \mathrm{~K} \text { wires }(1.2 \mathrm{~mm}) \text { on each fragment }\end{array}$ & Excellent \\
\hline 6 & $\begin{array}{l}10 \mathrm{~m}, \mathrm{~F}, \mathrm{Mix} \\
\text { Breed } \\
4 \mathrm{~kg}\end{array}$ & $\begin{array}{l}\text { Upper diaphyseal, } \\
\text { comminuted, } \\
\text { R tibia, } \\
\text { open-fracture, } \\
\text { 3-cm necrotic } \\
\text { segment in } \\
\text { distal fragment }\end{array}$ & $\begin{array}{l}\text { Open } \\
\text { approach }\end{array}$ & 45 days & $\begin{array}{l}1 \text { half ring on the proximal fragment }(5 \backslash 8) \\
1 \text { full ring on the proximal fragment } \\
1 \text { full ring on distal fragment (internal diameter } \\
55 \mathrm{~mm}) \\
3 \text {-cm block resection for bone lengthening }(0.5 \\
\mathrm{mm} \times 2 \text { times distraction, } 30 \text { days in total) } \\
1 \mathrm{~K} \text { wire }(1.2 \mathrm{~mm}) \text { on } 5 \backslash 8 \text { ring } \\
2 \mathrm{~K} \text { wires }(1.2 \mathrm{~mm}) \text { on full rings }\end{array}$ & Excellent \\
\hline 7 & $\begin{array}{l}1 \mathrm{y}, \mathrm{M}, \\
\text { Turkish Van, } \\
5 \mathrm{~kg}\end{array}$ & $\begin{array}{l}\text { Upper diaphyseal, } \\
\text { comminuted, } \\
\text { R tibia }\end{array}$ & $\begin{array}{l}\text { Open } \\
\text { approach }\end{array}$ & 45 days & $\begin{array}{l}1 \text { half ring on the proximal fragment }(5 \backslash 8) \\
1 \text { full ring on the upper diaphyseal region }(1 \backslash 3) \\
1 \text { full ring on the distal fragment (internal } \\
\text { diameter } 45 \mathrm{~mm}) \\
1 \mathrm{~K} \text { wire }(1.2 \mathrm{~mm}) \text { on } 5 \backslash 8 \text { ring } \\
2 \mathrm{~K} \text { wires }(1.2 \mathrm{~mm}) \text { on full rings }\end{array}$ & Good \\
\hline
\end{tabular}

M: months; y: years; w: weeks; M: male; MN: male neutered; F: female; FS: female spayed, TV: Turkish Van; MB: mixed breed; L: left; R: right.

M: Ay; y: yıl; W: hafta; M: erkek, MN: Kısır erkek; F: dişi; FS: kısır dişi; TV: Türk Van kedisi; MB: mix ırk; L: sol; R: sağ. 

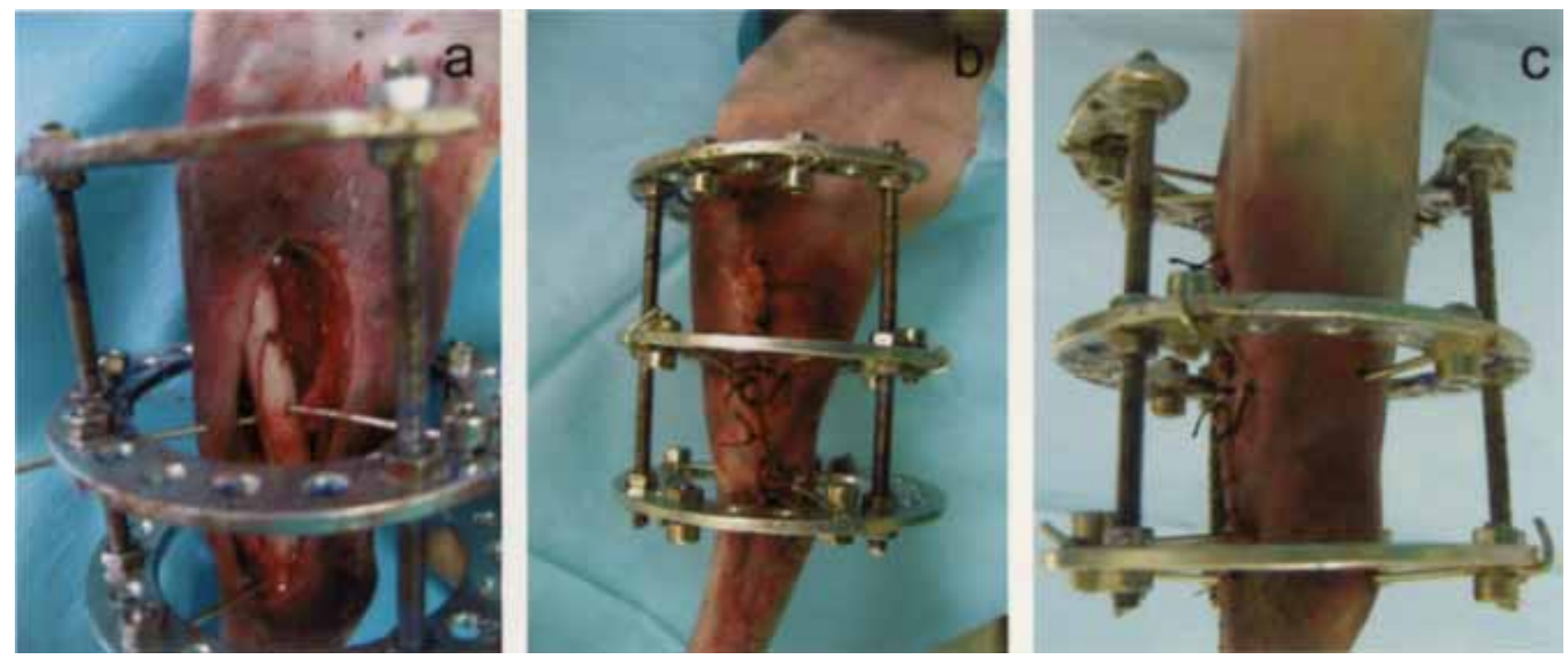

Figure 4. Intraoperative (a and b) and postoperative (c) appearances of case 6. One half ring was used on the proximal fragment (5\8), 1 full ring on the upper-diaphyseal region (1\3), 1 full ring on the distal fragment (internal diameter: $45 \mathrm{~mm}$ ), and $2 \mathrm{~K}$ wires (1.2 $\mathrm{mm}$ ) on each fragment.

Şekil 4. İntraoperatif (a ve b) ve postoperatif (c) pozisyonda 6 nolu olgunun görünüşü. Bir yarım halka proksimal fragmana (5\8), 1 tam halka üst-diafiz bölgesine (1\3), 1 tam halka distal fragmana (iç çapı: $45 \mathrm{~mm}$ ) ve $2 \mathrm{~K}$ teli (1.2 mm) her bir fragmana kullanıldı.
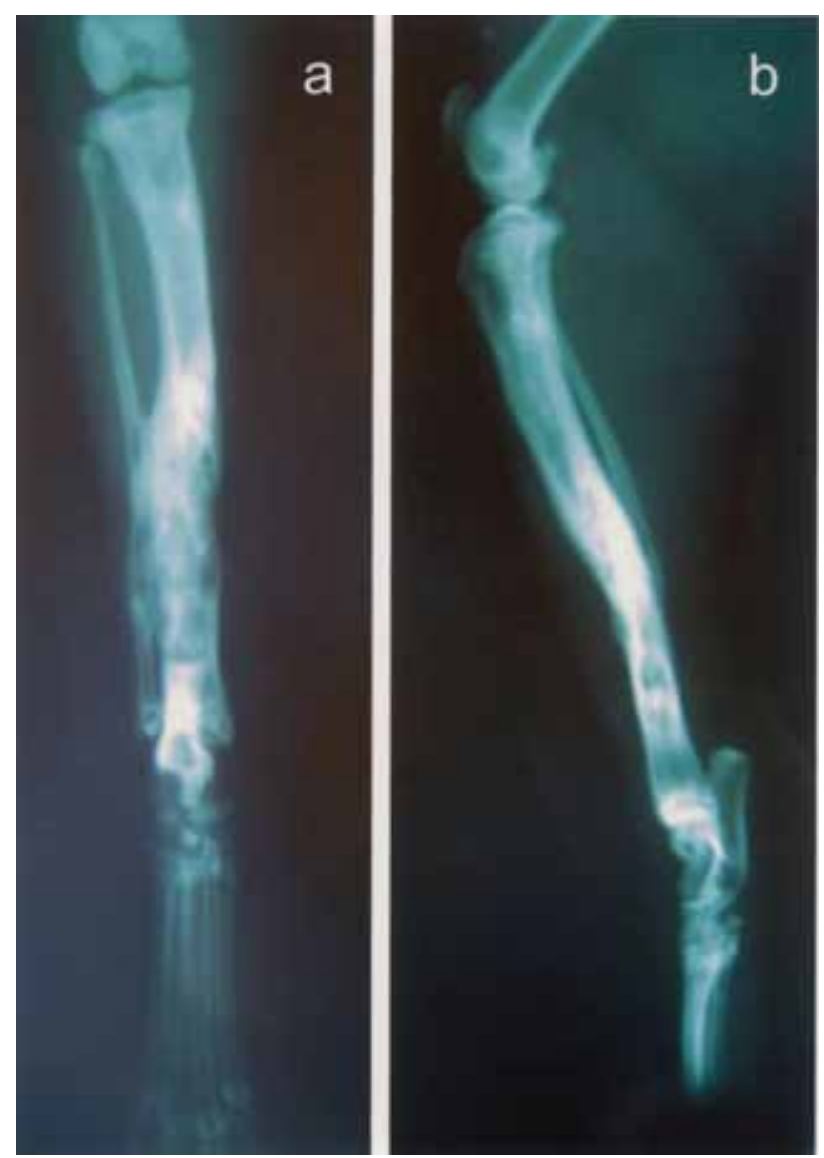

Figure 5. Postoperative craniocaudal (a) and mediolateral (b) radiographs of case 6 following fixator removal (45 day after surgery).

Şekil 5. 6 nolu olguda fiksatör uzaklaştırıldıktan sonra (45. günde) kraniokaudal (a) ve mediolateral (b) grafileri. was administered IM in all cases for postoperative 7-10 days. Postoperative bandages were not used, but to prevent pin track infection each pin insertion site was cleansed with $10 \%$ povidone-iodine solution t.i.d. Monthly follow-up examinations and radiographs were recommended to the cat's owners. The CEF was removed when the fracture was completely healed (Figure 5), and the owners were advised to limit their cat's movements for 10-15 days after removal.

\section{Results}

Signalment, fracture localization and type, complications, CEF removal time, configuration and diameter of rings and outcome for each case are listed in Table 1 . The cats were aged between 7 months-3 years, and weighed between 3.5 and $5 \mathrm{~kg}$. Surgical outcome was evaluated based on data collected from the cat owners, follow-up physical examinations, and radiographs, as well as clinical evaluation scale score (Table 2).

Table 2. Clinical evaluation scale.

Tablo 2. Klinik değerlendirme skalası.

\begin{tabular}{l} 
Clinical outcome \\
\hline Excellent: Normal limb function \\
Good: Mild, intermittent lameness \\
Fair: Mild to moderate lameness, but consistent weight \\
bearing \\
Poor: Non-weight bearing with severely limited activity. \\
\hline
\end{tabular}

Among the 7 cats, 7 diaphyseal fracture was observed. Open reduction was performed in 5 cases (cases 2, 4, 5, 6, and 7) versus limited open reduction in 2 cases (cases 1 and 3). The CEF system was used in 
each case and descriptions of the system's setup in each case are shown in Table 1.

The CEF system was well tolerated by all the cats during the postoperative follow-up period. First use of the treated limb occurred on postoperative 1-3 days in all cases. Radiological examination of the treated bones was performed on postoperative 25-48 days and the CEF was removed on postoperative 35-55 days. Superficial pin tract inflammation was observed in 2 cases (cases 3 and 7), which was cured in 15 days following appropriate daily pin track care. Pin deformation or CEF breakage and distortion were not observed in any of the cases. In terms of clinical outcomes, 5 cases were evaluated as excellent and 2 were evaluated as good (Table 2) according to the criteria given in Table 2.

\section{Discussion and Conclusion}

The method of fracture repair is based on fracture type and location, size and age of the animal, the number of bones and limbs involved, and concurrent soft tissue disease (3). Methods used to repair long bone fractures include bone plates, pins, wiring, external fixators, and interlocking nails $(9,21)$. Rigid stabilization must be maintained so that movements of the remnants of small bony particles are inhibited and prolonged callus formation and fracture healing is inhibited.

In this study use of the custom-designed CEF system for the treatment of tibial fractures resulted with success with minimal complications.

External coaptation is a commonly used method for simple transversal fractures distal to the elbow and stifle (9). The advantages of coaptation are that it's inexpensive and the materials necessary are readily available; its downside is that it requires substantial maintenance and is prone to complications (18). Use of the customdesigned CEF in the present study eliminated the need for additional bandaging. Daily cleansing of the treated limbs with an antibacterial agent was adequate for postoperative care.

Intramedullary pinning is widely used for long bone fracture repair in cats (18); however, the risk of intramedullary pins entering the adjacent joints in radius/ulna and tibia fractures limits the use of internal fracture fixation (1). The advantages of intramedullary pinning are its low cost, easy implantation, easy removal, and short implantation time. In addition, fixation with intramedullary pins is not very stable and bone union is secondary, and in animals treated with internal fracture fixation the return to normal function takes longer and post-surgical care is more intensive than that in animals treated with CEF. Internal fixation alone may be inadequate and sometimes secondary external support is necessary (3), as such, external fixator interlocking nail systems and plate/rod devices are recommended for use in all animals, and are more commonly used than internal fixation, coaptation, and wires.

Single use of an external skeletal fixation system is more expensive than intramedullary pinning; however, as the system can be reused its expense is lowered with each subsequent re-use. It is also reported that CEF is best suited for repair of tibial fractures, followed by the radius/ulna (18). The custom-designed CEF system described in this report was used in 7 cases with tibial fractures. In all cases the device was used safely and did not limit access to or visualization of the surgical site.

It is known that external fixation has advantages in the treatment of open and comminuted fractures (16), including minimal trauma to the adjacent structures, no permanent implantation required, and the fixation elements can be removed following bone union $(8,12)$. The custom-designed CEF system used in the present study was effective in offsetting long bone fractures in cats. Functional outcome was excellent in 5 of the 7 cases and 2 cases are evaluated as good due to pin tract infection. Pin tract infection is the most common complication observed in animals treated with external fixators $(2,4,13,16,20)$. In most cases of pin tract infection serous drainage is of the surface type. Pin tract drainage (11) was seen in the proximal lateral region in tibial fractures. Superficial pin tract infection occurred in 2 cases in the present study and daily antibacterial cleansing resolved the infections on 7 days.

It is suggested that in small animals fixation of fractures with 3 rings is generally difficult (4). In the present study incomplete rings (5\8 rings) were used to stabilize the proximal fracture segments and full rings were used to stabilize the distal segments in all cases. The open ends of the incomplete rings were directed caudally in the cats with tibial fractures, which facilitated full range of motion in the joint. In the present study there weren't any joint complications due to use of the custom-designed $\mathrm{CEF}$. Use of incomplete rings in the proximal segment of the fractures prevented the occurrence of joint motion limitations.

In all of the cases in the present study bone segments were fixated at multiple points using smalldiameter $(1.2 \mathrm{~mm})$ fixation wire placed in the rings at $90^{\circ}$. Based on biomechanical evaluation, wires placed at $90^{\circ}$ increased the stability of fixation and prevented bone segment translocation (10) Placement of fixation wires at $90^{\circ}$ combined with pin or plate fixation is best suited to oblique or spiral fractures in long bones when $\geq 2$ wires are employed (18). In the present study we used $1.2 \mathrm{~mm}$ fixation wires placed at $90^{\circ}$, which prevented bone segment translocation in all the cases, as reported by Lewis et al. (2001).

The custom-designed CEF system used in the present study can be used in cats easily because it is 
relatively light [(ETAL-74 $\quad(94 . \%$ aluminum, $1.5 \%$ magnesium, and $4.5 \%$ copper)] thus cats can carry the system easily. The system itself is designed particularly for cats with small diameter rings $(35 \mathrm{~mm}, 45 \mathrm{~mm}$ and 55 $\mathrm{mm}$ ) and the system also contains $5 / 8$ rings which is knew for the construction of the CEF system. Another advantage of the system is the pins can be inserted in 360 degree in all angles. Surgeon can make compression and distraction between the rings which cannot be made in the skeletal (SK) systems. Lastly CEF is biomechanically stronger than the SK and it maintains stronger and more rigid fixation compared to the SK system.

The custom-designed CEF system used in the present study was efficacious in the treatment of tibial fractures in cats.

\section{References}

1. Aslanbey D, Bilgili H (2000): The use of mini titanium plate fixation system in the repair of fractures in dogs and cats: 41 clinical cases. Turkish J Vet Surg, 6, 28-35.

2. Bilgili H, Kurum B, Captug O (2007): Treatment of radius-ulna and tibia fractures with circular external skeletal fixator in 19 dogs. Pol J Vet Sci, 10, 217-231.

3. De Young DJ, Probst CW (2003): Methods of internal fracture fixation. p.1610-1631 D. Slatter (Ed), In: Textbook of Small Animal Surgery, (vol 2). WB Saunders Philadelphia.

4. Farese JP, Lewis DD, Cross AR, et. al. (2002): Use of IMEX SK-Circular external fixator hybrid constructs for fracture stabilization in dogs and cats. J Am Vet Med Assoc, 38, 279-289.

5. Harasen G (2003): External coaptation of the distal radius and ulna fractures. Can Vet J, 44, 1010-1011.

6. Ilizarov GA (1990): Clinical application of tension-stress effect of limb lengthening. Clin Orthop Rel Res, 250, 8-26.

7. Johnson AL, Boone EG (2003): Fractures of the tibia and fibula. 1866-1876. D. Slatter (Ed), In: Textbook of Small Animal Surgery, (vol 2). WB Saunders Philadelphia.

8. Kirkby KA, Lewis DD, Lafuente MP, et. al. (2008): Management of humeral and femoral fractures in dogs and cats with linear-circular hybrid external fixators. J Am Anim Hosp Assoc, 44, 180-197.

9. Langley-Hobbs SJ, Voss K, Lapish JP, et al. (2009): Orthopedic material instruments implants \& techniques. 259-282. Montavon PM, Voss K, Langley-Hobbs SJ (Eds), In: Feline Orthopedic Surgery and Musculoskeletal Diseases. WB Sounders, Philadelphia.
10. Lewis DD, Bronson DG, Cross AR, et al. (2001): Axial characteristics of circular external fixator single ring constructs. Vet Surg, 30, 386-394.

11. Marcellin-Little DJ (1998): Hinged ilizarov external fixation for correction of antebrachial deformities. Vet Surg, 27, 231-245.

12. Ness MG Treatment of inherently unstable open or infected fractures by open wound management and external skeletal fixation. J Small Anim Pract, 47, 83-88.

13. Paley D (1990): Problems, obstacles and complications of limb lengthening by the Ilizarov technique. Clin Orthop Rel Res, 250, 81-104.

14. Pardo AD (2003): Cerclage wiring and tension band fixation. 1631-1640 Slatter D (ed), In: Textbook of Small Animal Surgery, (vol 2). W.B. Saunders, Philadelphia.

15. Philips IR (1979): A survey of bone fracture in the dog and cat. J Small Anim Pract, 20, 661.

16. Rovesti GL, Bosio A, Marcellin-Little DJ (2007): Management of 49 antebrachial and crural fractures in dogs using circular external fixator. J Small Anim Pract, 48, 194-200.

17. Sardinas JC, Montavon PM (2005): Use of a medial bone plate for repair of radius and ulna fractures in dogs and cats: A report of 22 cases. Vet Surg, 26, 108-113.

18. Scott H (2005): Repair of long bone fractures in cats. In Practice 27: 390-397.

19. Sumner-Smith G, Cawley AJ (1970): Non-union fractures in the dog. J Small Anim Pract, 11, 311.

20. Theyse LFH, Voorhout G, Hazewinkel HAW (2005): Prognostic factors in treating antebrachial growth deformities with a lengthening procedure using a circular external skeletal fixation system in dogs. Vet Surg, 34, 424-435.

21. Worth AJ (2007): Management of fractures of the long bones of eight cats using external skeletal fixation and a tied-in intra-medullary pin with a resin-acrylic bar. New Zeal Vet J, 55, 191-197.

Geliş tarihi: 20.12.2013 / Kabul tarihi: 17.03.2014
Address for correspondence:
Prof. Dr. H. Bilgili,
Department of Surgery,
Faculty of Veterinary Medicine,
Ankara University,
06110 Dışkapı, Ankara, Turkey.
e-mail:hbilgilitr@yahoo.com 